Printed in Great Britain

\title{
MASSIVE UPWARD DISPLACEMENT IN THE DEEP OCEAN
}

\author{
By L. H. N. COOPER \\ The Plymouth Laboratory \\ (Text-figs. I and 2)
}

For a third of a century many and varied studies on sea water have been concentrated upon a single accessible shallow-water station in the English Channel, EI, supplemented by more extensive excursions usually designed to test working hypotheses. This concentration of effort has been richly rewarded. In deep-water oceanography a similar approach is appropriate; a standard station, 'Cavall' has therefore been selected in the north-eastern Bay of Biscay in $4700 \mathrm{~m}$ of water at lat. $46^{\circ} 30^{\prime} \mathrm{N}$., long. $8^{\circ} \mathrm{o0^{ \prime }}$ W., nominal, a position worked by the Danish Research Vessel 'Dana' in 1922 and 1930. It is not only the nearest deep water position to Plymouth but it has best possible coverage by the Decca Navigator system. For our experimental programme it is essential that the station positions be maintained and repeated precisely. To achieve this a working Decca chartlet (Fig. I) on a scale of $1: 20,000$ has been prepared for each station from a portion of the Admiralty Decca Lattice chart no. $\mathrm{L}_{\mathrm{I}} \mathrm{IO}_{4}$. On this a circle of radius one mile is inscribed. Throughout operations the ship is maintained within this circle by stopping work when necessary and steaming back on Decca co-ordinates towards the centre, or beyond to pre-compensate expected drift.

On a number of occasions the deep-water station Cavall has been fixed astronomically. The position found is $6 \mathrm{~km}$ from the nominal. The discrepancy may arise from error in the 50-fold expansion of the small scale chart or from distortion of the Decca Lattice over the sea area. It is of no practical consequence so that, although a correction could now be made, to do so would lead only to confusion. In station lists and precision statements the astronomical fix, $46^{\circ} 27^{\prime} \mathrm{N}$., $8^{\circ} \mathrm{o} 2^{\prime}$ W., will need to be reported but in descriptive statements the easily remembered nominal position will continue to be used. In both cases the over-riding definition is by Decca co-ordinates: Red G 2I.55, Green D 44.90, which alone matter for navigation.

Two more standard stations (Table I) have been established on course from Plymouth over the continental slope of La Chapelle Bank and one precisely at the break of slope which is very sharp (Cartwright, 1959, Fig. 2, upper). A further shallow water station over the Bank is sometimes worked 9 miles within the break of slope. 
It has become essential to have convenient names for these stations and I have selected some from Celtic mythology.

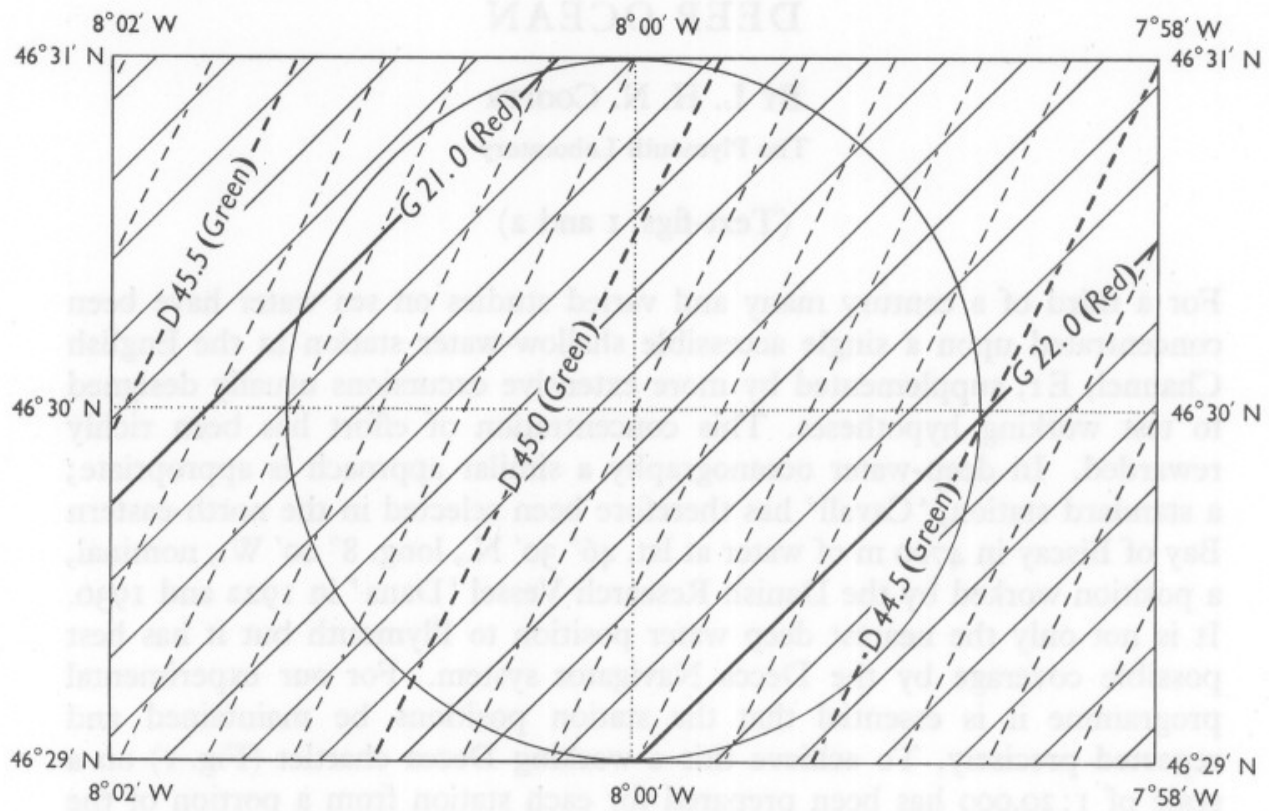

Fig. I. Working chartlet (scaled $\mathrm{I}: 20,000$ ) used for maintaining station Cavall within a circle of radius I mile using the Decca Navigator system.

TABLE 1. POSITION OF STANDARD STATIONS, BAY OF BISCAY AND LA CHAPELLE BANK

\begin{tabular}{|c|c|c|c|c|c|c|c|}
\hline & \multicolumn{2}{|c|}{$\begin{array}{l}\text { Nominal } \\
\text { position }\end{array}$} & \multicolumn{2}{|c|}{$\begin{array}{l}\text { Astronomical } \\
\text { position }\end{array}$} & \multicolumn{2}{|c|}{$\begin{array}{c}\text { Decca } \\
\text { Co-ordinates }\end{array}$} & \multirow{2}{*}{$\begin{array}{c}\text { Depth } \\
\text { (m) }\end{array}$} \\
\hline & \multirow{2}{*}{$\begin{array}{l}\text { Lat. } \\
\text { N. }\end{array}$} & $\begin{array}{l}\text { Long. } \\
\text { W. }\end{array}$ & \multirow{2}{*}{$\begin{array}{l}\text { Lat. } \\
\text { N. }\end{array}$} & $\begin{array}{l}\text { Long. } \\
\text { W. }\end{array}$ & & & \\
\hline $\begin{array}{l}\text { Station } \\
\text { Geraint }\end{array}$ & & & & $\begin{array}{l}\text { W. } \\
\text { nown }\end{array}$ & $\begin{array}{c}\text { Red } \\
\text { F } 22.20\end{array}$ & $\begin{array}{l}\text { Green } \\
\text { D } 45.00\end{array}$ & (m) \\
\hline 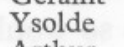 & $47^{\circ} 35^{\prime}$ & $7^{\circ} 12^{\prime}$ & Not & nown & $\mathrm{G} 02.50$ & D 44.60 & I $75-185$ \\
\hline thur & $47^{\circ} 30^{\prime}$ & $7^{\circ} 18^{\prime}$ & Not & nown & $\mathrm{G} 03.69$ & D 45.57 & Variable $800-$ \\
\hline divere & $47^{\circ} 20^{\prime}$ & $7^{\circ} 22^{\prime}$ & Not & nown & $\mathrm{G} 08.46$ & D 44.28 & Variable $3100-3800$ \\
\hline ivall & $46^{\circ} 30^{\prime}$ & $8^{\circ} \mathrm{oo}^{\prime}$ & $46^{\circ} 27$ & $8^{\circ} \mathrm{O}^{\prime}$ & G 21.55 & D 44.90 & 4710 \\
\hline
\end{tabular}

\section{UPWARD DISPLACEMENT}

Views already published (Cooper, I955 $a, b$, I956; cf. Dietrich, I956) require that room for the water sinking into the eastern North Atlantic from the Iceland-Faroe Ridge may be found only by upward displacement somewhere or other of water already there. In any one year it was envisaged that this effect would not exceed 7-10 m and that northern water was most unlikely to intrude at the very bottom of the ocean. The 1956 programme was designed 

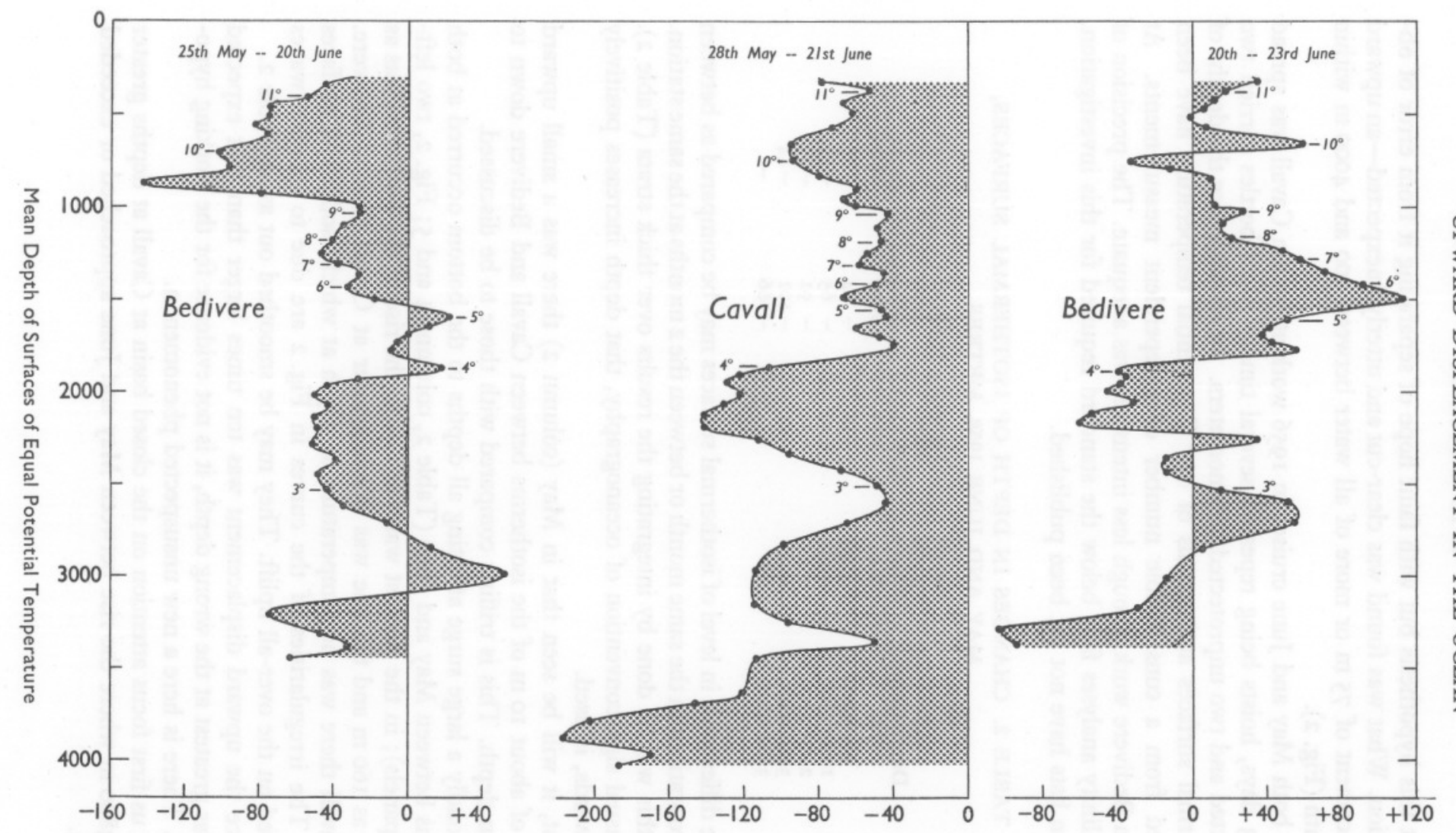

Change in Level of Surfaces of Equal Potential Temperature

Fig. 2. Changes in level of surfaces of equal potential temperature in the Bay of Biscay, May and June 1956, plotted against weighted mean depths of the surfaces. All depths and levels in metres. 
to test this hypothesis but with faint hope of separating it from error of observation. What was found was clear-cut and utterly unexpected-an upward displacement of $75 \mathrm{~m}$ or more of all water between 300 and $4000 \mathrm{~m}$ within a month (Fig. 2).

On both May and June cruises in 1956 work at station Cavall was spread over 3 days, hoists being repeated several times. Most bottles carried two protected and two unprotected thermometers. In consequence the depths of isothermal surfaces at intervals of $0 . \mathrm{I}^{\circ} \mathrm{C}$ potential temperature have been derived from a considerable number of independent measurements. At station Bedivere work, though less intensive, was adequate. The precision of the salinity analyses falls below the standard required for this investigation. Station lists have not yet been published.

TABLE 2. CHANGES IN DEPTH OF ISOTHERMAL SURFACES, MAY AND JUNE 1956, METRES

$\begin{array}{ccccc}\begin{array}{c}\text { Depth range } \\ (\mathrm{m})\end{array} & \begin{array}{c}\text { Cavall } \\ \text { minus } \\ \text { Bedivere: } \\ \text { May }\end{array} & \begin{array}{c}\text { Cavall } \\ \text { minus } \\ \text { Bedivere: } \\ \text { June }\end{array} & \begin{array}{c}\text { Cavall: } \\ \text { June } \\ \text { minus }\end{array} & \begin{array}{c}\text { Bedivere: } \\ \text { June } \\ \text { minus } \\ \text { May }\end{array} \\ \begin{array}{c}\text { Mao-1000 } \\ 1000-2000\end{array} & +\mathrm{r} 3 & +\mathrm{r} 8 & -74 & -79 \\ 2000-3000 & +6 & -42 & -65 & -17 \\ 3000-3500 & +12 & -52 & -91 & -27 \\ 3500-4000 & -4 & -6 \mathrm{I} & -\mathrm{IOI} & -44 \\ & - & - & -\mathrm{I} 66 & -\end{array}$

The differences in level of isothermal surfaces may be compared as between the two stations in the same month or between the 2 months at the same station. First this will be done by integrating the results over thick strata (Table 2). The usual sign convention of oceanography, that depth increases positively downwards, is used.

First, it will be seen that in May (column 2) there was a small upward trend of about Io $\mathrm{m}$ of the isotherms between Cavall and Bedivere down to $3000 \mathrm{~m}$ depth. This is trifling compared with those to be discussed.

Secondly a large surge affecting all depths to the bottom occurred at both stations between May and June (Table 2, columns 4 and 5; Fig. 2, two lefthand panels); in the deepest water at Cavall the rise in the isotherms was as much as $160 \mathrm{~m}$ and the rise was much greater at Cavall than at Bedivere. At Cavall there was no temperature or depth at which isothermal surfaces sank. The irregularities of the curves in Fig. 2 are due to internal waves imposed on the over-all uplift. They may be smoothed out as in Table 2 .

Since the upward displacement was ten times larger than that expected and was greatest at the wrong depth, it is not evidence for the working hypothesis. There is here a new unsuspected phenomenon.

Let us first focus attention on the closed basin at Cavall at depths greater than $3800 \mathrm{~m}$ where the rise between May and June approached or exceeded $200 \mathrm{~m}$. 
First, let us assume that some kind of abyssal surge, internal wave or seiche occurred within the basin. If so the isotherms on the south-western side of the basin should have been falling while those on the north-eastern were rising. The event occurred where small changes in temperature and of salinity so nearly compensate each other that the abyssal water within very narrow limits is in neutral dynamic equilibrium. In such water it is difficult to visualize any kind of wave or seiche. Oscillations would seem to involve large changes in momentum though the energy involved must be very small, much too small to lift an overlying body of water, $3500 \mathrm{~m}$ thick through $70-100 \mathrm{~m}$. This first assumption therefore is highly improbable.

Secondly, let us assume that a new supply of very heavy water entered the basin upwardly displacing the water already there. On this explanation, the maximum upward displacement at a mean depth of about $3900 \mathrm{~m}$ was about $2 \mathrm{IO} \mathrm{m}$. This explanation requires rapid transport of a very large volume of water from an unknown source. It could provide the means of uplifting all the overlying water. The content of silicate does not agree with recruitment of much water from the north. The existence of the Mid-Atlantic and Walvis Ridges would make it difficult for a large scale flow of water to have come from the far south. The second assumption, in this form, is as improbable as the first. It can be modified to yield a third assumption.

Thus, thirdly, let us assume that the basin of the eastern North Atlantic may exhibit large-scale oscillations and displacements of water which affect all of it at once. The oscillations of the deepest waters would then be not a cause but a consequence of the massive displacements of the overlying more strongly stratified waters.

The least controversial explanation of the observations is therefore that within the 3 weeks between the May and June cruises we witnessed a massive oscillation of the whole of the eastern North Atlantic with a displacement of water at all depths between about $300 \mathrm{~m}$ and the bottom, reminiscent of the internal tide waves discussed by Defant (1950). On this view the massive oscillation was part of an equilibrium long-period tide, probably the lunar fortnightly or lunar monthly constituent (Doodson \& Warburg, I94I, p. 49). In the 3 days between 20 and 23 June at station Bedivere, the movement of isothermal surfaces was predominantly downwards (Fig. 2, right-hand panel); this phasing rather favours the lunar fortnightly tide. As Defant pointed out, internal tide waves gravely interfere with the design of experiment in the deep ocean since the amplitudes of motions due to internal tides may be larger than those of the displacement phenomena we wish to study.

My hypotheses to explain the enrichment in the I920's of the English Channel with nutrients require first that there should have been a longperiod upward displacement of nutrient levels in the eastern North Atlantic, and that secondly there should have been an intensification of the internal waves beating against the continental slope. On a first appreciation the 
upward displacement of about $75 \mathrm{~m}$ in May-June 1956 provided very strong evidence. But as time passed, no consequent enrichment of the waters of the English Channel followed so that, it would seem, such massive upward displacements may be commonplace and may not provide an explanation of the enrichment of the English Channel in the I920's.

Again, since the sea surface cannot be displaced upwards by more than a few centimetres, the upwardly displaced water had to escape as horizontal currents at depths between the surface and $300 \mathrm{~m}$, so influencing the pattern of surface currents in the Bay of Biscay. If the deep oscillation was tidal, the consequent pattern of surface currents was also tidal and should be identifiable with a harmonic component in tidal analyses around southwestern Britain.

TABLE 3. CHANGE IN POTENTIAL TEMPERATURE WITH TIME

$\begin{array}{cccc}\text { Caribbean, } & \text { Bay of Biscay, } & \text { Ratio: } \\ \text { Depth } & \begin{array}{c}\text { March I933 to } \\ \text { December I954 }\end{array} & \begin{array}{c}\text { 28 May to 2I June } \\ \text { Biscay/ } \\ \text { Caribbean }\end{array} \\ \text { I500 } & +0.047 & -0.45 & -9.6 \\ 1600 & +0.036 & -0.21 & -5.8 \\ 1750 & +0.024 & -0.15 & -6.3 \\ 2000 & +0.015 & -0.13 & -8.7 \\ 2500 & +0.008 & -0.08 & -10 \\ 3000 & +0.005 & -0.08 & -16\end{array}$

If we were dealing solely with upward displacement the concentration of oxygen, phosphate and silicate would have moved precisely with temperature. This was not so at any depth. Consequently upward displacement must have been accompanied by considerable horizontal displacement.

Worthington (1955) published observations to suggest that the deep water of the Caribbean is warming up (Table 3). By the same argument the Bay of Biscay would be cooling down very fast. The fall in temperature within 24 days in the summer of 1956 was ten times larger that the rise within 21 years in the Caribbean. Table 3 points the need for great caution in assessing long-term changes in the deep ocean from the scanty data we have.

\section{SUMMARY}

A set of 'standard' stations has been established in the Bay of Biscay and related to the grid of the Decca Navigator system. Whilst on station the ship is maintained within a circle of radius I mile.

In May and June 1956 repetitive hoists were made to the bottom at station Cavall ( $4700 \mathrm{~m}$ deep) and Bedivere at the foot of the continental slope. In 3 weeks there was a large upward displacement of all isotherms, averaging about $40 \mathrm{~m}$ at Bedivere and $80 \mathrm{~m}$ at Cavall, over all depths between 300 and $3500 \mathrm{~m}$. The upward displacement was even greater at 3500-4000 $\mathrm{m}$ depth.

Oscillations in the ocean abyss and inflows at the bottom of Arctic and Antarctic waters are examined and dismissed as likely explanations. The least 
controversial explanation is that a massive oscillation of the whole of the eastern North Atlantic occurred in June 1956. This may have been a long period tidal phenomenon.

At standard depths the fall in temperature in 24 days was ten times greater than changes in the Caribbean reported as evidence for long-term warming-up of the ocean.

\section{REFERENCES}

Cartwright, D. E., 1959. On submarine sand-waves and tidal lee-waves. Proc. roy. Soc. A, Vol. 253, pp. 218-4I.

Cooper, L. H. N. I955a. Deep water movements in the North Atlantic as a link between climatic changes around Iceland and the biological productivity of the English Channel and Celtic Sea. F. mar. Res., Vol. 14, pp. 347-62.

- 1955b. Hypotheses connecting fluctuations in Arctic climate with biological productivity in the English Channel. Deep-Sea Res. Suppl. to Vol. 3, Pap. mar. Biol. E Oceanogr., pp. 212-23.

— I956. On assessing the age of deep oceanic water by carbon-I4. F. mar. biol. Ass. U.K., Vol. 35, pp. 34I-54.

DEFAnT, A., I950. On the origin of internal tide waves in the open sea. F. mar. Res., Vol. 9, pp. III-I9.

DIETRICH, G., 1956. Ưberstromung des Island-Färöer-Rückens in Bodennähe nach Beobachtungen mit dem Forschungsschiff 'Anton Dohrn' 1955/56. Dtsch. Hydrogr. Z., Bd. 9, pp. 78-89.

Doodson, A. T. \& WARBURG, H. D., I94I. Admiralty Manual of Tides. London: H.M.S.O.

WoRTHINGTON, L. V., I955. A new theory of Caribbean bottom-water formation. Deep-Sea Res., Vol. 3, pp. 82-7. 